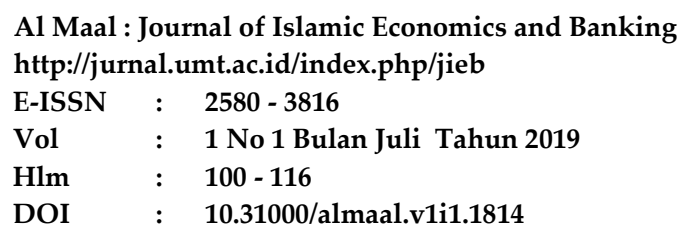

\title{
Riba Dalam Al-Quran Dan Strategi Menghadapinya
}

\author{
Ahmad Naufal 1,* \\ ${ }^{1}$ Prodi Ekonomi Syariah, Institut Bisnis Muhammadiyah Bekasi, Bekasi, Indonesia \\ *Email: agamnaufal@gmail.com
}

\begin{abstract}
The systemic practice of usury has caused the monetary sector to separate from the real sector, causing a prolonged economic downturn. This has actually been warned in the Qur'an. For this reason, this study aims to explore the "warning" about usury in the Qur'an, including finding solutions. With the method of interpretation of maudhu'i's conclusions, it was concluded that the prohibition of usury because of usury contained dangers and impacts both micro and macro. The gradual prohibition of usury gives an understanding that in order to deal with the usury system a planned stage and strategy is needed. And the main strategy to deal with the usury system is to promote charity and alms.
\end{abstract}

Keyword: Usury; Zakat; Al Qur'an

\begin{abstract}
ABSTRAK
Praktek riba yang sistemik telah menyebabkan terpisahnya sektor moneter dengan sektor riil, sehingga menimbulkan keterpurukan ekonomi yang berkepanjangan. Hal ini sebenarnya telah diperingatkan dalam al-Qur'an. Karena itulah, penelitian ini bertujuan untuk menggali kembali "peringatan" mengenai riba di dalam al-Qur'an, termasuk mencari solusi pemecahannya. Dengan metode analisis tafsir maudhu'i didapat kesimpulan bahwa diharamkannya riba karena riba mengandung bahaya dan dampak baik secara mikro maupun makro. Bertahapnya pengharaman riba memberi pemahaman bahwa untuk menghadapi sistem riba juga diperlukan tahapan dan strategi yang terencana. Dan strategi

utama untuk menghadapi sistem riba adalah dengan menggalakkan zakat dan sedekah. Kata kunci: Riba; Zakat; Al Quran
\end{abstract}




\section{Pendahuluan}

Dalam pandangan seorang banker/debitur, sistem bunga yang dilandasai saling ridha dan (terkesan) tidak menzalimi, dianggap sebagai sebuah sistem yang wajar dan tidak menjadi masalah. Bahkan bersifat positif-konstruktif bagi masyarakat. Padahal di dalam al-Qur'an status riba sudah final.

Dari sisi penawaran, riba adalah komponen yang menyebabkan naiknya harga barang dan jasa akibat naiknya biaya produksi. Sehingga hal tersebut berpotensi menimbulkan inflasi. Dari sisi permintaan, riba yang telah menjadi komponen harga menyebabkan bertambahnya beban yang harus dibayar oleh konsumen, dan berpotensi menciptakan pengisapan kekayaan konsumen oleh produsen dan pemilik modal. Kenaikan tingkat suku bunga (riba) akan berdampak pada turunnya investasi. Demikian pula sebaliknya, turunnya suku bunga akan mendorong pertumbuhan investasi. Terganggunya investasi akan menyebabkan terganggunya produksi dan sisi supply dalam perekonomian. (Lajnah Pentashihan Mushaf al-Qur'an, 2009)

Praktek riba telah menyebabkan terpisahnya sektor moneter dengan sektor riil yang dalam istilah kontemporer disebut derivatif. Sistem bisnis derivatif ini telah membawa banyak negara ke jurang krisis. Riba menjadi penyebab utama semua bencana ekonomi besar yang terjadi sejak tahun 1929 di Amerika Serikat; terjadinya crash pasar saham Wall Street tahun 2001 yang dikenal sebagai Black Monday; krisis keuangan dan perbankan di tahun 1987; krisis finansial Asia 1997/ 1998; penyebab ambruknya bank dagang tertua Inggris, Barrings Bank; kolapsnya Enron; pemicu krisis ekonomi Argentina; serta menjadi pemantik krisis keuangan dan ekonomi global. (http://agustiantomingka.wordpress.com)

Dari sekian banyak dampak yang ditimbulkan riba, maka muncul satu pertanyaan, bagaimana menghadapi sistem ribawi yang telah sedemikian lama berurat-berakar dalam nadi kehidupan masyarakat? Tentu jawabannya harus dicari di dalam al-Qur'an. Inilah yang menjadi isu sentral dalam artikel ini. Sebab, secara prinsip Allah tidak mungkin memerintahkan untuk meninggalkan sesuatu yang besar dan berat, tanpa menjelaskan bahayanya dan memberikan solusi pemecahannya.

\section{Hasil dan Pembahasan}

\section{Definisi Riba Menurut Para Ulama}

Riba, secara bahasa bermakna bertambah dan tumbuh. (Ibn Mandzûr, tt) Sementara secara istilah para ulama mendefinisikannya sebagai berikut:

Definisi Hanâbilah

$$
\text { الزّيادة في أشياء مخصوصة. }
$$

"Tambahan pada suatu barang tertentu.” (Ibn Qudâmah, 1981: 3)

Definisi Syâfi'iyyah

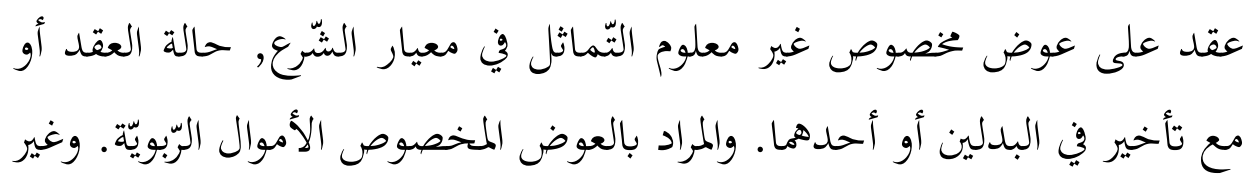




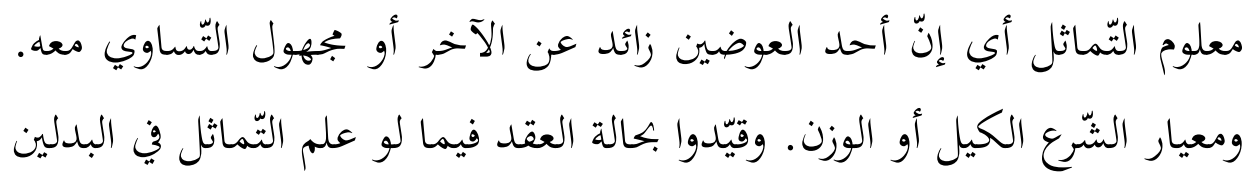

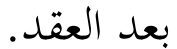

"Akad pada pengganti tertentu yang tidak sepadan dalam timbangan syar'i, baik dalam akad kontan maupun kredit dalam kedua penggantinya atau salah satunya. Dan yang dimaksud dengan 'pengganti tertentu' adalah barang-barang ribawi. Sedangkan yang dimaksud dengan 'tidak sepadan' adalah adanya tambahan pada salah satu pengganti atau tidak adanya persamaan. Dan 'timbangan syar'i' maksudnya adalah takaran atau timbangan. Sementara dikaitkan dengan 'akad kontan' jika sekiranya diketahui kesepadanan pada keduanya setelah akad." (Ash-Shaghîr, tt)

Definisi Hanâfiyyah

$$
\begin{aligned}
& \text { الفضل المستحقّ لأحد المتعاقدين في المعاوضة, الخالي عن عوض شُرط فيه. أي } \\
& \text { الزّيادة لأحد المتعاقدين في عقود المعاوضة فقط. فلا تدخل الهبة لأَّّا ليست } \\
& \text { معاوضة, والزّيادة هنا لا يقابلها شيء وتكون هذه الزّيادة ربا. }
\end{aligned}
$$

"Kelebihan yang menjadi hak dari salah satu pihak dalam transaksi, terlepas dari pengganti yang disyaratkan. Artinya tambahan bagi salah satu pihak hanya dalam akad-akad transaksi saja. Maka hibah tidak termasuk, karena bukan transaksi. Dan 'tambahan' di sini tidak ada penggantinya atau penyeimbangnya, maka tambahan itu adalah riba." (Al-Marghainânî, $\mathrm{tt}$ )

Definisi Mâlikiyyah

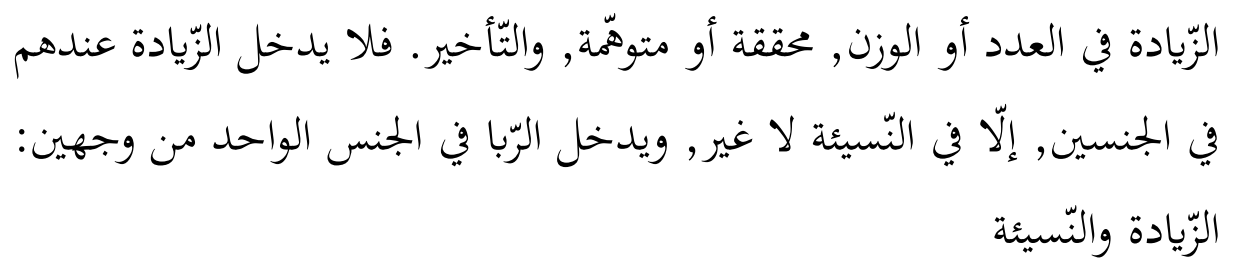

"Tambahan pada jumlah atau timbangan, ditentukan atau tidak, dan pada tempo. Maka menurut mereka, tidak termasuk adanya tambahan pada pertukaran barang yang sejenis kecuali pada nasî'ah (tempo). Dan termasuk riba dalam satu jenis dari dua sisi; tambahan dan tempo." (AlQurthubî, tt)

Definisi Ibn ‘Abbâs

$$
\text { الزيادة في آخر البيع بعدما حل الأجل كالزيادة في أول البيع إذا بعت بالنسيئة }
$$

"Tambahan pada akhir jual beli setelah tempo berakhir seperti pada awal jual beli ketika dijual dengan tempo" (Ibn “Abbâs, tt)

Definis Muhammad ‘Ali ash-Shâbûnî 


$$
\text { زيادة يأخذها المقرض من المستقرض مقابل الأجل. }
$$

"Tambahan yang diambil oleh pemberi pinjaman dari si peminjam karena adanya tempo.” (Ash-Shâbûnî, 1999)

Dari beberapa pengertian yang dirumuskan oleh para ulama tersebut, secara umum terdapat benang merah yang menegaskan bahwa riba adalah pengambilan tambahan, baik dalam transaksi jual beli maupun pinjam meminjam secara bathil atau bertentangan dengan prinsip muamalah Islam. (Antonio, 2005)

\section{Jenis-Jenis Riba}

Secara umum riba dapat dikelompokkan menjadi dua, yaitu riba utang dan riba jual beli. Riba utang terbagi menjadi dua, yaitu ribâ qard dan ribâ jâhiliyyah. Sementara riba jual beli terbagi juga menjadi dua, ribâ fadhl dan ribâ nasî'ah. (Antonio, 2005)

Riba Qard (ربا قرض ) adalah suatu manfaat atau tingkat kelebihan tertentu yang disyaratkan terhadap yang berutang.

Riba Jâhiliyyah ( ربا جاهلية ) adalah utang dibayar lebih dari pokoknya karena si peminjam tidak mampu membayar utangnya pada waktu yang ditetapkan.

Riba fadhl ( ربا فضل ) adalah pertukaran antar barang sejenis dengan kadar atau takaran berbeda, sedangkan barang yang dipertukarkan itu termasuk dalam jenis barang ribawi.

Riba nasîah ( ربا نسيئة ) adalah penangguhan penyerahan atau penerimaan jenis barang ribawi yang dipertukarkan dengan jenis barang ribawi lainnya. Riba dalam nasî‘ah muncul karena adanya perbedaan, perubahan, atau tambahan antara yang diserahkan saat ini dan yang diserahkan kemudian.

\section{Riba Di Dalam Al-Qur'an}

\section{Ayat-Ayat Tentang Riba Berdasarkan Masa Turunnya}

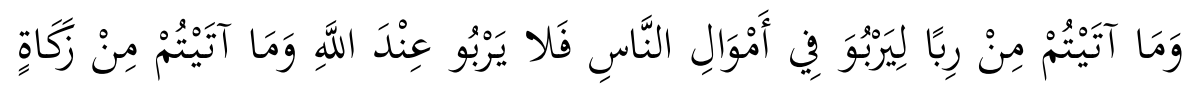

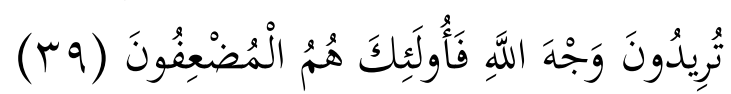

"Dan sesuatu Riba (tambahan) yang kamu berikan agar dia bertambah pada harta manusia, Maka Riba itu tidak menambah pada sisi Allah. dan apa yang kamu berikan berupa zakat yang kamu maksudkan untuk mencapai keridhaan Allah, Maka (yang berbuat demikian) itulah orang-orang yang melipat gandakan (pahalanya)." (Qs. Ar-Rûm: 39)

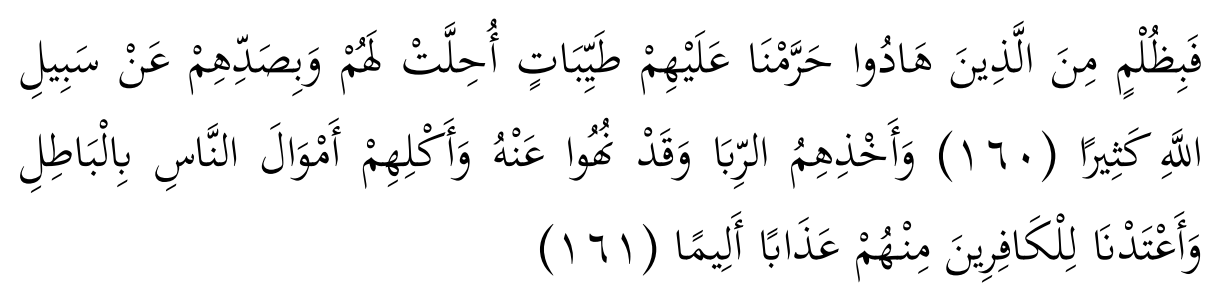

"Maka disebabkan kezaliman orang-orang Yahudi, Kami haramkan atas (memakan makanan) yang baik-baik (yang dahulunya) dihalalkan bagi mereka, dan karena mereka banyak menghalangi (manusia) dari 
jalan Allah. Dan disebabkan mereka memakan riba, padahal sesungguhnya mereka telah dilarang daripadanya, dan karena mereka memakan harta benda orang dengan jalan yang batil, Kami telah menyediakan untuk orang-orang yang kafir di antara mereka itu siksa yang pedih." (Qs. An-Nisâ': 160-161)

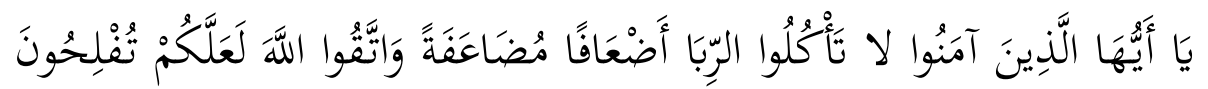

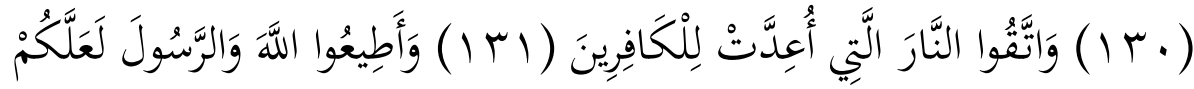

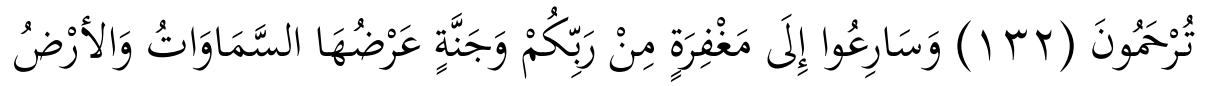

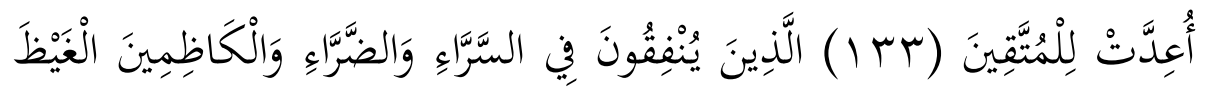

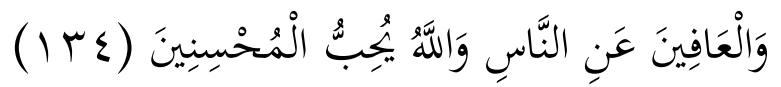

"Hai orang-orang yang beriman, janganlah kamu memakan riba dengan berlipat ganda dan bertakwalah kamu kepada Allah supaya kamu mendapat keberuntungan. Dan peliharalah dirimu dari api neraka, yang disediakan untuk orang-orang yang kafir. Dan taatilah Allah dan Rasul, supaya kamu diberi rahmat. Dan bersegeralah kamu kepada ampunan dari Tuhanmu dan kepada surga yang luasnya seluas langit dan bumi yang disediakan untuk orang-orang yang bertakwa. (Yaitu) orang-orang yang menafkahkan (hartanya), baik di waktu lapang maupun sempit, dan orang-orang yang menahan amarahnya dan mema'afkan (kesalahan) orang. Allah menyukai orang-orang yang berbuat kebajikan.” (Qs. Ali 'Imrân: 130-134)

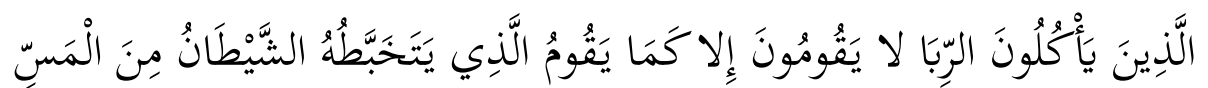

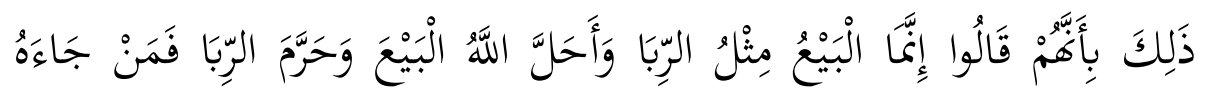

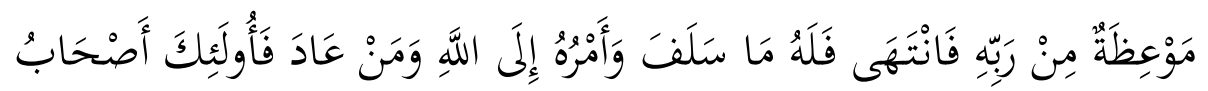

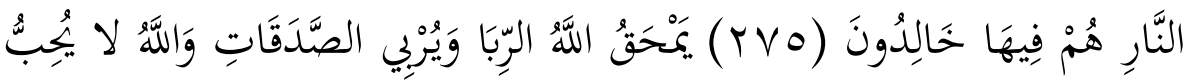

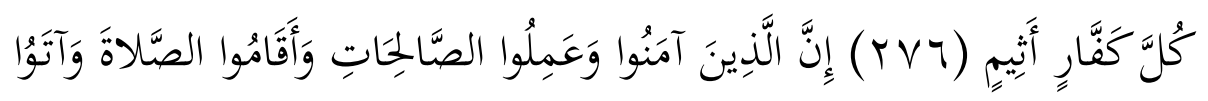

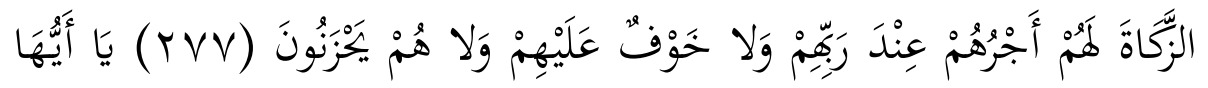

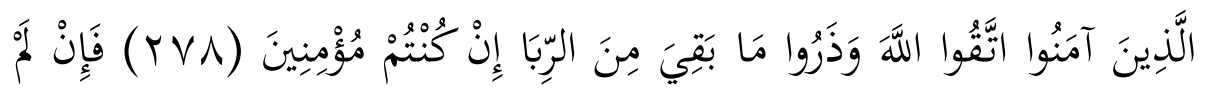

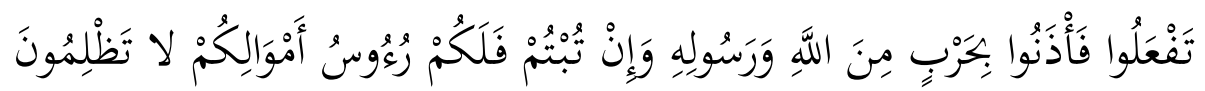

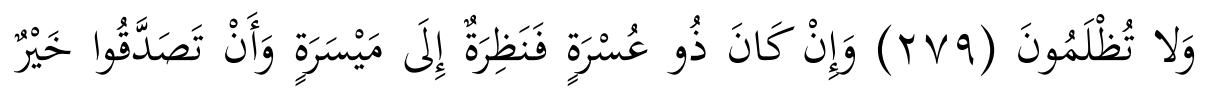




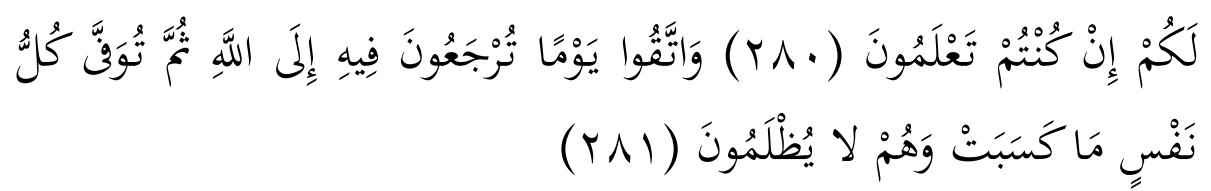

"Orang-orang yang makan (mengambil) riba tidak dapat berdiri melainkan seperti berdirinya orang yang kemasukan syaitan lantaran (tekanan) penyakit gila. Keadaan mereka yang demikian itu, adalah disebabkan mereka berkata (berpendapat), sesungguhnya jual beli itu sama dengan riba, padahal Allah telah menghalalkan jual beli dan mengharamkan riba. Orang-orang yang telah sampai kepadanya larangan dari Tuhannya, lalu terus berhenti (dari mengambil riba), maka baginya apa yang telah diambilnya dahulu (sebelum datang larangan); dan urusannya (terserah) kepada Allah. Orang yang kembali (mengambil riba), maka orang itu adalah penghuni-penghuni neraka; mereka kekal di dalamnya. Allah memusnahkan Riba dan menyuburkan sedekah. dan Allah tidak menyukai Setiap orang yang tetap dalam kekafiran, dan selalu berbuat dosa. Sesungguhnya orangorang yang beriman, mengerjakan amal saleh, mendirikan shalat dan menunaikan zakat, mereka mendapat pahala di sisi Tuhannya. tidak ada kekhawatiran terhadap mereka dan tidak (pula) mereka bersedih hati. Hai orang-orang yang beriman, bertakwalah kepada Allah dan tinggalkan sisa Riba (yang belum dipungut) jika kamu orang-orang yang beriman. Maka jika kamu tidak mengerjakan (meninggalkan sisa riba), maka ketahuilah, bahwa Allah dan Rasul-Nya akan memerangimu. dan jika kamu bertaubat (dari pengambilan riba), maka bagimu pokok hartamu; kamu tidak menganiaya dan tidak (pula) dianiaya. Dan jika (orang yang berutang itu) dalam kesukaran, Maka berilah tangguh sampai Dia berkelapangan. dan menyedekahkan (sebagian atau semua utang) itu, lebih baik bagimu, jika kamu mengetahui. Dan peliharalah dirimu dari (azab yang terjadi pada) hari yang pada waktu itu kamu semua dikembalikan kepada Allah. kemudian masing-masing diri diberi Balasan yang sempurna terhadap apa yang telah dikerjakannya, sedang mereka sedikitpun tidak dianiaya (dirugikan)." (Qs. Al-Baqarah: 275-281)

\section{Munâsabah Ayat}

Para ulama menawarkan satu cara agar pemahaman terhadap al-Qur'an agar tidak parsial, yaitu dengan pendekatan munâsabah. Munâsabah adalah berbagai hubungan antara ayat atau surat yang sedang dipahami maksudnya; ada munâsabah antara awal surat dengan akhir surat sebelumnya, antara awal dengan akhir surat yang sama, antara kandungan surat dengan namanya, antara kelompok ayat dengan ayat-ayat sebelum dan sesudahnya, dan lain-lain. (Zuhri, 1997)

Munâsabah ini diperlukan karena ayat-ayat tentang riba dalam al-Qur'an terdapat pada beberapa tempat dan masa turunnya berbeda-beda. Ayat pertama turun di Makkah, dan ayat-ayat selanjutnya turun di Madinah. Tahapan turunnya ayat riba ini mirip seperti tahapan turunnya ayat khamr. (Al-Marâghî, tt)

Tahap pertama, riba diungkap pertama kali oleh al-Qur'an pada periode Makkah, dalam surat ar-Rûm: 39. Dari ayat itu diketahui bahwa masyarakat Makkah dan sekitarnya 
sebagian telah mempraktekkan riba dan sebagian telah membayar zakat. Agaknya mereka menghendaki agar harta yang mereka miliki dapat menjadi banyak, dan jalan yang ditempuh adalah praktek riba. Tetapi pada saat itu Allah Swt. belum mengharamkan riba. Allah tidak mengatakan bahwa orang yang mengambil riba akan mendapat siksa. Allah hanya mengingatkan bahwa zakatlah yang menghasilkan lipat ganda seperti yang mereka kehendaki, bukan riba.

Ayat ini mengisyaratkan kebencian Allah terhadap riba, dengan mengatakan bahwa riba tidak akan mendapat pahala di sisi Allah. Jadi, ayat pertama ini hanya berupa peringatan bahwa riba adalah suatu yang negatif.

Tahap kedua, ayat tentang riba turun di Madinah, dalam surat an-Nisâ': 160-161. Dalam ayat ini meskipun Allah tidak secara tegas melarang orang Islam mengambil riba, tetapi melalui ayat ini Allah hendak memberi pelajaran atau 'ibrah, dengan menceritakan sikap orang-orang Yahudi terhadap riba yang telah Allah haramkan kepada mereka, tapi mereka justru melanggarnya. Maka mereka berhak mendapat laknat dan siksa.

Jadi, tahapan yang kedua ini adalah tahapan pengharaman dengan isyarat dan sindiran, belum secara terang-terangan. Karena kisah tentang haramnya riba yang ditujukan kepada orang-orang Yahudi tidak secara qath' $i$ berarti riba juga diharamkan kepada orang-orang Islam.

Ketika al-Qur'an menyebut riba di surat ini, Ia tidak mengontraskannya dengan zakat atau padanannya pada ayat sebelumnya, tetapi menyejajarkan pelaku riba dengan orang yang durhaka kepada Rasul. Lihat misalnya surat an-Nisâ’: 155-156

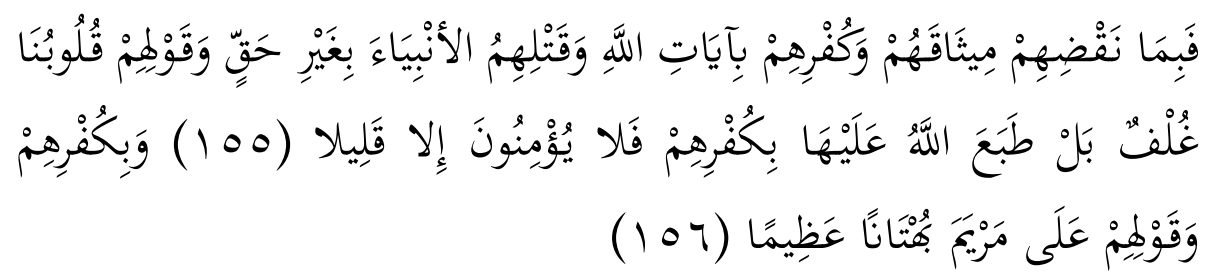

"Maka (kami lakukan terhadap mereka beberapa tindakan), disebabkan mereka melanggar perjanjian itu, dan karena kekafiran mereka terhadap keterangan-keterangan Allah dan mereka membunuh nabi-nabi tanpa (alasan) yang benar dan mengatakan: "hati kami tertutup." Bahkan, sebenarnya Allah telah mengunci mati hati mereka karena kekafirannya, karena itu mereka tidak beriman kecuali sebahagian kecil dari mereka. Dan karena kekafiran mereka (terhadap Isa) dan tuduhan mereka terhadap Maryam dengan kedustaan besar (zina).” (Qs. an-Nisâ: 155-156)

Setelah al-Qur'an menyebut bahaya praktek riba di kalangan orang Yahudi (Qs. an-Nisâ': 161), ia menyebut beberapa sifat orang yang akan mendapat pahala dari sisi Allah, satu di antaranya adalah orang yang mengeluarkan zakat. Al-Qur'an surat anNisầ: 162 menjelaskan: 


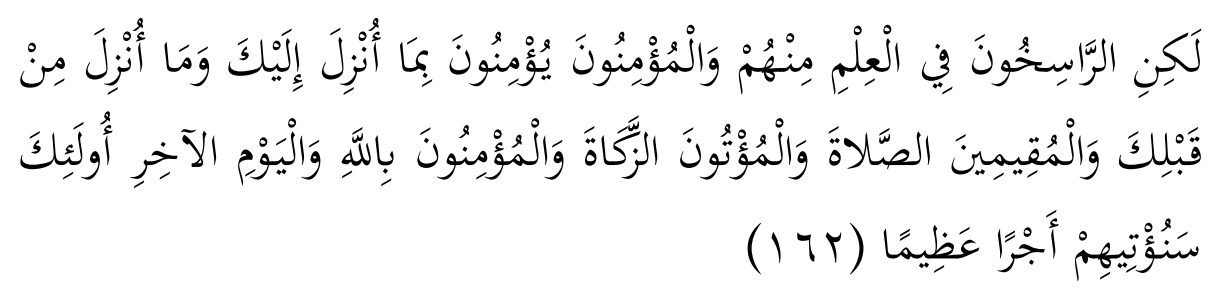

"Tetapi orang-orang yang mendalam ilmunya di antara mereka dan orang-orang mukmin, mereka beriman kepada apa yang telah diturunkan kepadamu (Al Quran), dan apa yang telah diturunkan sebelummu dan orang-orang yang mendirikan shalat, menunaikan zakat, dan yang beriman kepada Allah dan hari kemudian. orang-orang itulah yang akan Kami berikan kepada mereka pahala yang besar." (Qs. an-Nisâ: 162)

Tahap ketiga. Pelarangan praktek riba baru disebut secara eksplisit dalam surat Âli 'Imrân: 130. Ayat ini turun di Madinah pada tahun ke-3 Hijriyah. Tentang sebab turunnya ayat tersebut, Mujahid mengatakan,

"Orang-orang Arab sering mengadakan transaksi jual beli tidak tunai. Jika jatuh tempo sudah tiba dan pihak yang berhutang belum mampu melunasi maka nanti ada penundaan waktu pembayaran dengan kompensasi jumlah uang yang harus dibayarkan juga menjadi bertambah, maka Allah menurunkan ayat di atas." (Al-Qurthubî, 1964)

Dalam ayat ini pengharaman riba sudah jelas, tapi baru bersifat parsial, yaitu yang dikaitkan dengan tambahan yang terus bertambah hingga mencapai berlipat ganda atau yang dinamakan dengan ar-ribâ al-fâhisy (riba yang keji). Tetapi ayat ini bukan merupakan syarat dari terjadinya riba (jika berlipat ganda maka riba, tetapi jika kecil maka bukan riba). Ayat ini merupakan sifat umum dari praktek pembungaan uang yang umum terjadi pada masa itu.

Pada masa jahiliyah, riba memiliki beberapa bentuk, yaitu: (Ash-Shâwî dan AlMushlih, 2008)

Pertama, riba pinjaman, yang direfleksikan dalam satu kaidah di masa jahiliyah, "tangguhkanlah hutangku, dan aku akan menambahnya". Misalnya seseorang memiliki hutang. Ketika tiba waktu pembayaran, orang yang berhutang itu tidak mampu melunasinya. Akhirnya ia berkata, "tangguhkan hutangku, aku akan memberikan tambahan". Maksudnya, perlambatlah masa pembayarannya, dan aku akan menambah jumlah hutang yang akan kubayar. Penambahan itu bisa dengan cara melipatgandakan hutang, atau (bila berupa hewan) dengan menambah umur hewan.

Wahbah az-Zuhailî menjelaskan dalam tafsirnya bahwa diantara bentuk riba dalam pinjaman adalah mensyaratkan adanya tambahan dalam pinjaman ketika habis masa pinjamannya, karena adanya tempo waktu tertentu. Riba seperti inilah yang biasanya terjadi pada masa Jahiliyah di kalangan orang-orang Arab. Mereka tidak mengenal selain riba ini. Mereka biasanya membayar utang yang telah mereka pinjam tiap bulan dengan jumlah tertentu (menyicil). Jika masa tempo sudah habis, semua utang mereka akan ditagih. Dan jika tidak bisa membayar maka utang akan ditambah (riba) dan tempo pun akan diperpanjang. Biasanya mereka memberi opsi "apakah akan dilunasi atau utangnya ditambah?" Artinya, utang akan bertambah dengan bertambahnya tempo. (AzZuhailî, 1998) 
Kedua, pinjaman dengan pembayaran tertunda, namun dengan syarat harus dibayar dengan bunganya. Hutang itu dibayar sekaligus pada saat berakhirnya masa pembayaran.

Al-Jashshâsh menyatakan, "riba yang dikenal dan biasa dilakukan oleh masyarakat Arab adalah berbentuk pinjaman uang dirham atau dinar yang dibayar secara tertunda dengan bunganya dengan jumlah sesuai dengan jumlah hutang dan sesuai dengan kesepakatan bersama." berkala).

Ketiga, pinjaman berjangka dan berbunga dengan syarat dibayar perbulan (secara

Ibn Hajar al-Haitsamî menyatakan, "riba nasî'ah adalah riba yang populer di masa jahiliyah. Karena biasanya seseorang meminjamkan uangnya kepada orang lain untuk dibayar secara tertunda, dengan syarat ia mengambil sejumlah uang tertentu tiap bulannya dari orang yang berhutang, sementara modalnya tetap. Apabila datang waktu pembayaran, ia menuntut pembayaran uang yang ia hutangkan. Kalau mereka tidak mampu melunasinya, waktu pembayaran diundur dan ia harus menambah jumlah uang yang harus dibayar."

Tampaknya, pelarangan ini merupakan jumlah mu'taridhah dalam rangkaian besar ayat-ayat antara 121-138. Menurut Muhammad 'Abduh, sebelum al-Qur'an menyebut larangan riba di ayat 130, ia berbicara tentang pertolongan Allah kepada orang mukmin dalam perang Badr. Surat Âli 'Imrân: 121-127 menuturkan:

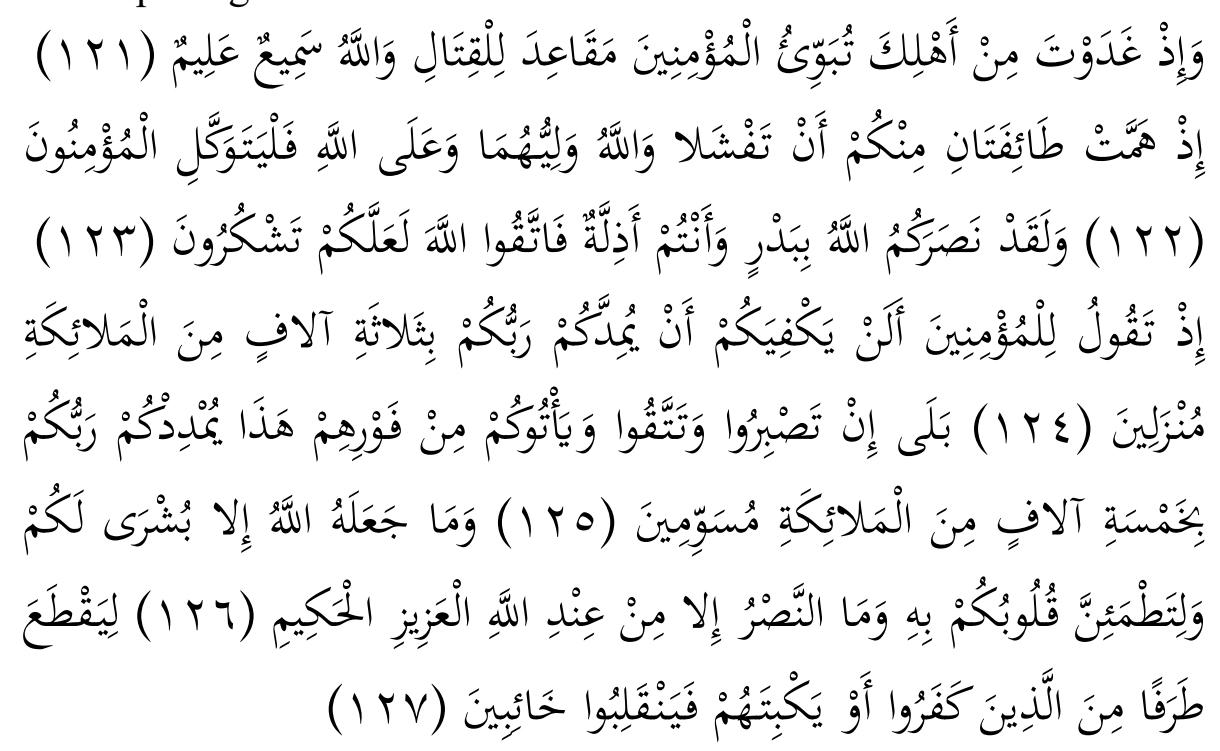

"Dan (ingatlah), ketika kamu berangkat pada pagi hari dari (rumah) keluargamu akan menempatkan Para mukmin pada beberapa tempat untuk berperang, dan Allah Maha mendengar lagi Maha mengetahui. Ketika dua golongan dari padamu ingin (mundur) karena takut, Padahal Allah adalah penolong bagi kedua golongan itu. karena itu hendaklah kepada Allah saja orang-orang mukmin bertawakkal. Sungguh Allah telah menolong kamu dalam peperangan Badar, padahal kamu adalah (ketika itu) orang-orang yang lemah, karena itu bertakwalah kepada Allah, supaya kamu mensyukuri-Nya. (Ingatlah), ketika kamu mengatakan kepada orang mukmin: "Apakah tidak cukup bagi kamu Allah membantu kamu dengan tiga ribu Malaikat yang diturunkan (dari langit)?" Ya (cukup), jika kamu bersabar dan bersiapsiaga, dan mereka datang menyerang kamu dengan seketika itu juga, 
niscaya Allah menolong kamu dengan lima ribu Malaikat yang memakai tanda. Dan Allah tidak menjadikan pemberian bala bantuan itu melainkan sebagai khabar gembira bagi (kemenangan)mu, dan agar tenteram hatimu karenanya. dan kemenanganmu itu hanyalah dari Allah yang Maha Perkasa lagi Maha Bijaksana. (Allah menolong kamu dalam perang Badar dan memberi bala bantuan itu) untuk membinasakan segolongan orang-orang yang kafir, atau untuk menjadikan mereka hina, lalu mereka kembali dengan tiada memperoleh apa-apa.” (Qs. Âli ‘Imrân: 121-127)

"Kekalahan" dalam perang Uhud berkaitan dengan ketamakan orang Islam akan ghanâmah dan keakraban mereka dengan orang-orang Yahudi yang dikenal pemakan riba, seperti disebut dalam surat an-Nisầ: 160-161. Agar pertolongan Allah tetap menyertai mereka, tamak harta dan akrab dengan pemakan riba harus disingkiri. (Zuhri, 1997)

Kalau menjelang penyebutan riba dalam surat ar-Rûm al-Qur'an menyebutkan bahwa pemberi rizki adalah Allah (dalam ayat itu ditunjukkan kekuasaannya), maka menjelang pelarangan riba di surat Âli 'Imrân al-Qur'an juga menyebutkan kekuasaanNya atas langit dan bumi, dan kekuasaan-Nya mengampuni serta mengazab manusia. Surat Âli 'Imran: 129 menyebutkan:

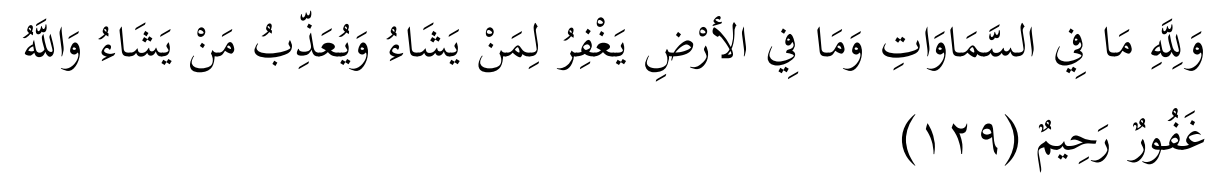

"Kepunyaan Allah apa yang ada di langit dan yang ada di bumi. Dia memberi ampun kepada siapa yang Dia kehendaki; Dia menyiksa siapa yang Dia kehendaki, dan Allah Maha Pengampun lagi Maha Penyayang. ” (Qs. Âli ‘Imrân: 129)

Agaknya penyebutan ini merupakan ancang-ancang agar seruan pada kalimat berikutnya (tentang larangan riba) dipatuhi, dengan kesadaran bahwa seruan itu dari Allah Yang Maha Kuasa; dan mengabaikannya berarti kufur.

Setelah al-Qur'an menyebut larangan riba, pada ayat selanjutnya Allah menakuti-nakuti dengan neraka. Banyak pakar tafsir yang menjelaskan bahwa ayat ini merupakan ancaman keras untuk orang-orang yang membolehkan transaksi riba. Siapa saja yang menganggap transaksi riba itu halal/ boleh maka dia adalah orang yang kafir dan divonis kafir meski masih mengaku sebagai seorang muslim. Ada juga pakar tafsir yang menjelaskan bahwa maksud ayat, waspadailah amal-amal yang bisa mencabut iman kalian sehingga kalian wajib masuk neraka. Di antara amal tersebut adalah durhaka kepada orang tua, memutus hubungan kekerabatan, memakan harta riba dan khianat terhadap amanat. (http://muslim.or.id/)

Jika riba dilarang, infak harta (baik dalam keadaan lapang maupun sempit), menahan marah, memaafkan orang, berbuat ihsân diperintahkan dengan jaminan surga (Qs. Âli 'Imrân: 134).

Tahap keempat. Ayat terakhir yang turun berbicara tentang riba adalah surat alBaqarah: 278-279. Ayat ini turun pada tahun ke-9 Hijriyah terkait dengan kasus Bani Tsaqîf dan Bani Mughîrah. Imam ath-Thabarî meriwayatkan dari Ibn Juraij: 


$$
\begin{aligned}
& \text { كانت ثقيف قد صالحت النبيّ صلى الله عليه وسلم على أنّ ما لهم من ربًا } \\
& \text { على الناس وما كان للناس عليهم من ربًا فهو موضوع. فلما كان الفتحُ، } \\
& \text { استعمل عتَّاب بن أسِيد على مكةَّ، وكانت بنو عمرو بن عُمير بن عوف } \\
& \text { يأخذون الرّبا من بني المغيرة، وكانت بنو المغيرة يُرْبون لهم في الجاهلية، فجاء } \\
& \text { الإسلام ولمم عليهم مال كثير. فأتاهم بنو عمرو يطلبون رباهم، فأبي بنو المغيرة } \\
& \text { أن يعطوهم في الإسالام، ورفعوا ذلك إلى عتّاب بن أسيد، فكتب عتّاب إلى } \\
& \text { رسول الله صلى الله عليه وسلم، فنزلت:"يا أيها الذين آمنوا اتقوا الله وذروا ما } \\
& \text { بقي من الرّبا إن كنتم مؤمنين . فإن لم تفعلوا فأذنوا بكرُب من الله ورسوله"، } \\
& \text { إلى"ولا تظلمون". فكتب بها رسول الله صلى الله عليه وسلم إلى عتّاب } \\
& \text { وقال:"إن رَضوا وإلا فآذهم بحرب. }
\end{aligned}
$$

"Kaum Tsaqif (penduduk kota Thaif) telah membuat suatu kesepakatan dengan Rasulullah Saw. bahwa semua utang dan piutang (tagihan) mereka yang berdasarkan riba agar dibekukan dan dikembalikan hanya pokoknya saja. Setelah penaklukan Makkah, Rasulullah menunjuk Attâb bin Asîd sebagai Gubernur Makkah (yang juga meliputi kawasan Thaif sebagai daerah administrasinya). Bani Amr bin 'Umair bin 'Auf adalah orang yang senantiasa meminjamkan uang secara riba kepada Bani Mughîrah dan sejak zaman Jahiliyah Bani Mughîrah senantiasa membayarnya dengan tambahan riba. Setelah kedatangan Islam, mereka tetap memiliki kekayaan dan aset yang banyak. Maka datanglah Bani Amr untuk menagih utang dengan tambahan (riba) dari Bani Mughîrah (seperti biasanya), tetapi Bani Mughîrah setelah masuk Islam menolak memberi tambahan (riba) tersebut. Lalu mereka melaporkan masalah tersebut kepada Gubernur Attâb bin Asîd. Kemudian Itab langsung menulis surat kepada Rasulullah Saw. dan turunlah ayat (Qs. al-Baqarah: 278-279). Rasulullah Saw. lantas menulis surat kepada Attâb, 'jika mereka ridha atas ketentuan Allah tersebut maka itu baik, tetapi jika mereka menolaknya maka kumandangkanlah perang kepada mereka'." (AthThabarî, 2000)

Dalam kelompok ayat ini Allah Swt. sudah secara tegas mengharamkan riba secara mutlak, baik sedikit maupun banyak. Jika dilihat dari ayat 261, al-Qur'an memulai pembicaraan tentang riba dengan menegaskan bahwa orang yang berinfak di jalan Allah berarti melipatgandakan harta. Al-Qur'an memuji mereka yang menginfakkan tanpa embel-embel (Qs. al-Baqarah: 262). Dalam infak tidak ada pembatasan jenis barang. Pandangan bahwa infak membuat jatuh miskin ditolak oleh al-Qur'an, dengan mengatakan bahwa justru infak menguntungkan pelakunya (Qs. al-Baqarah: 272). Ia dijamin pahala berlipat ganda dan dijauhkan dari rasa takut dan gelisah (Qs. al-Baqarah: 
274). Jaminan yang sama diulang kembali dalam ayat 277 sesudah Allah mempertentangkan riba dengan sedekah (Qs. al-Baqarah: 276-277), karena orang menyangka bahwa riba sama halalnya dengan jual beli (Qs. al-Baqarah: 275).

Berdasarkan munâsabah di atas diketahui bahwa setiap kali al-Qur'an berbicara tentang riba, istilah zakat atau padanannya selalu diiringi antitesanya. Di surat ar-Rûm, an-Nisâ dan Âli 'Imrân, antitesa tersebut disebutkan setelah al-Qur'an berbicara tentang riba, dan pada kelompok surat al-Baqarah, antitesa itu disebut sebelumnya.

Dengan praktek riba maka fungsi sosial harta kekayaan menjadi tidak ada, sehingga kesenjangan antara kaya dan miskin menonjol. Sedangkan dalam zakat dan sedekah, fungsi sosial harta diperankan sehingga hubungan antara orang kaya dan miskin terjalin baik.

Riba dikontraskan dengan zakat terkandung isyarat yang harus dipahami bahwa keduanya memiliki sifat yang sama sekali bertentangan. Dalam zakat terkandung pemberian ikhlas, dalam riba terkandung pemerasan.

\section{Penjelasan Ayat}

Menurut pandangan kebanyakan manusia, pinjaman dengan sistem bunga akan dapat membantu ekonomi masyarakat yang pada gilirannya akan meningkatkan pertumbuhan ekonomi rakyat. Anggapan tersebut telah menjadi keyakinan kuat hampir setiap orang, baik ekonom, pemeritah maupun praktisi.

Keyakinan kuat itu juga terdapat pada intelektual Muslim terdidik yang tidak berlatar belakang pendidikan ekonomi. Karena itu banyak para pejabat negara dan direktur perbankan yang bangga melaporkan jumlah kredit yang dikucurkan untuk pengusaha kecil sekian puluh triliun rupiah. Begitulah pandangan dan keyakinan hampir semua manusia saat ini dalam memandang sistem kredit dengan instrumen bunga. Itulah pandangan material (zahir) manusia yang seringkali terbatas.

Pandangan umum di atas dibantah oleh Allah dalam Qs. ar-Rûm : 39, “Apa yang kamu berikan (berupa pinjaman) dalam bentuk riba agar harta manusia bertambah, maka hal itu tidak bertambah di sisi Allah." Ayat ini menyampaikan pesan moral, bahwa pinjaman (kredit) dengan sistem bunga tidak akan membuat ekonomi masyarakat tumbuh secara agregat (menyeluruh) dan adil.

Al-Quran membicarakan riba (bunga) dalam ayat tersebut dalam konteks ekonomi makro, bukan "hanya" ekonomi mikro. Bahkan sisi ekonomi makro jauh lebih besar. Kesalahan manusia kapitalis, termasuk ahli agama Islam yang tak berlatar belakang ekonomi, adalah menempatkan dan membahas riba dalam konteks ekonomi mikro semata. Membicarakan riba dalam konteks ekonomi makro adalah mengkaji dampak riba terhadap ekonomi masyarakat secara agregat, bukan individu atau perusahaann (institusi). (http://www.pesantrenvirtual.com)

Sedangkan membicarakan riba dalam lingkup mikro, adalah membahas riba hanya dari sisi hubungan kontrak antara debitur dan kreditur. Biasanya yang dibahas berapa persen bunga yang harus dibayar oleh si A atau perusahaan $\mathrm{X}$ selaku debitur kepada kreditur. Juga, apakah bunga yang dibayar debitur sifatnya memberatkan atau menguntungkan.

Padahal dalam ayat, al-Quran menyoroti praktek riba yang telah sistemik, yaitu riba yang telah menjadi sistem di mana-mana, riba yang telah menjadi instrumen ekonomi, sebagaimana yang diyakini para penganut sistem ekonomi kapitalisme.

Dalam sistem kapitalis, bunga bank (interest rate) merupakan jantung dari sistem perekonomian. Hampir tak ada sisi dari perekonomian, yang luput dari mekanisme kredit bunga bank (credit system). Mulai dari transaksi lokal pada semua struktur ekonomi 
negara, hingga perdagangan internasional. Jika riba telah menjadi sistem yang mapan dan telah mengkristal sedemikian kuatnya, maka sistem itu akan dapat menimbulkan dampak buruk bagi perekonomian secara luas.

Al-Qur'an selalu membicarakan riba dengan kalimat أكل ( yang artinya makan). Maksudnya adalah mengambil atau memanfaatkan riba, karena 'memakan' itulah tujuan asalnya. Artinya, bahwa sebagian besar pemanfaatan harta riba itu adalah untuk dimakan. Makna ini juga mencakup mengambil dan memberikan. (Az-Zuhailî, 1998) Sebagaimana sabda Rasulullah Saw:

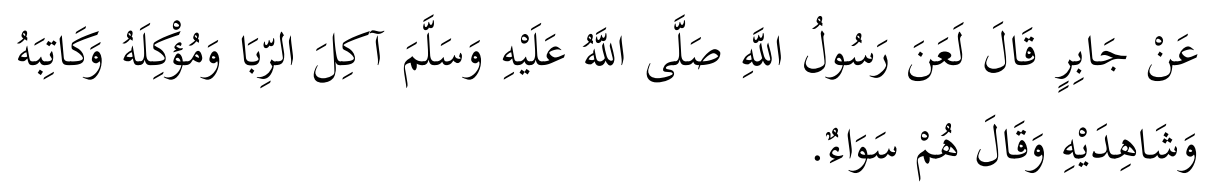

Dari Jabir, dia berkata, "Rasulullah Saw. melaknat pemakan riba, orang yang menyuruh makan riba, juru tulisnya dan saksi-saksinya." Dan beliau bersabda, "Mereka semua sama." (HR. Muslim no. 2995)

Dalam Qs. al-Baqarah: 275-278, Allah menjelaskan bahwa orang-orang yang memakan riba, menghalalkannya karena kecintaan terhadap harta atau menuruti hawa nafsu, memakan harta orang lain dengan jalan yang bathil, serta tanpa usaha dan jerih payah, mereka akan selalu beraktivitas dengan diliputi rasa gelisah, tidak tentram, selalu bingung dan selalu berada dalam ketidakpastian, disebabkan karena pikiran mereka selalu tertuju kepada materi dan penambahan harta. (Shihab, 2000)

Allah memperumpamakan perilaku yang demikian itu seperti orang gila dan kesurupuan jin. Dan mereka pada hari kiamat kelak ketika bangkit dari kuburnya, akan lebih dahsyat lagi keguncangan dan kegilaannya karena beratnya harta riba yang telah mereka makan. (Az-Zuhailî, 1998) Bagaimana dahsyatnya siksa para pemakan riba, tergambar dalam hadis Rasulullah Saw berikut:

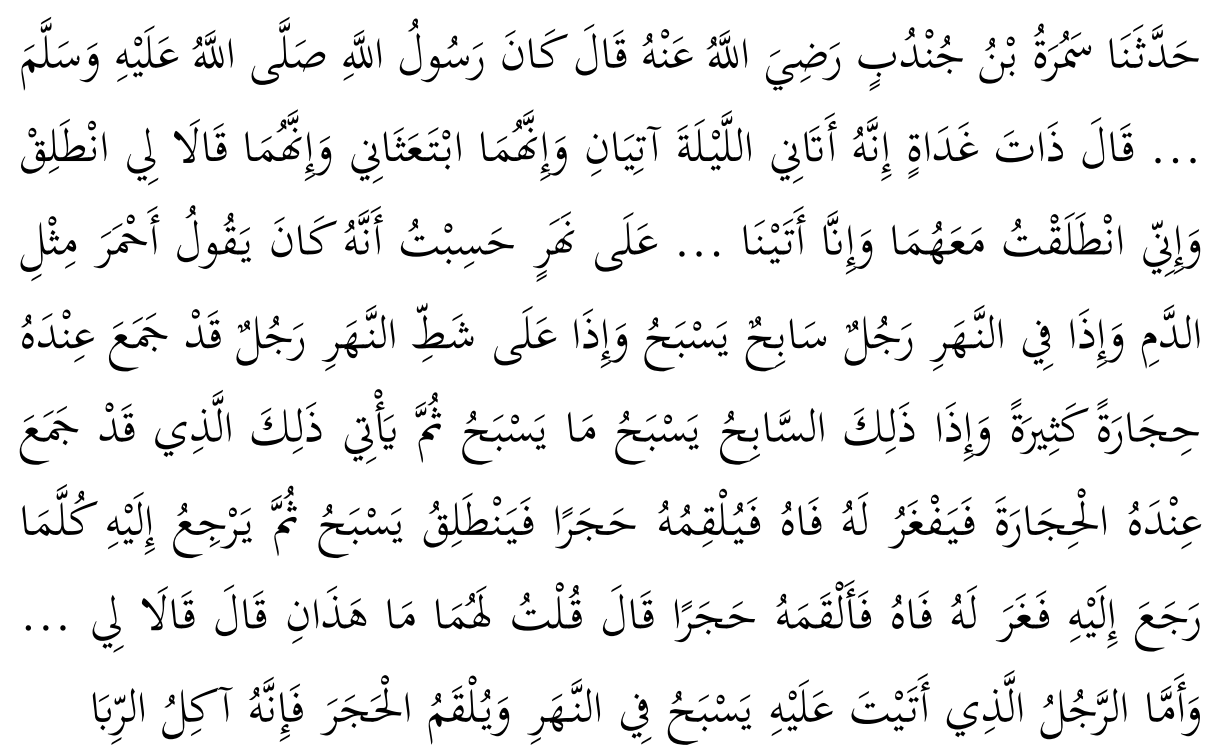

Diriwayatkan dari Samurah bin Jundub r.a., Rasulullah Saw. bersabda: "Semalam aku bermimpi didatangi dua orang, keduanya mengajakku pergi dan berujar; 'Ayo kita berangkat!' Aku pun berangkat bersama keduanya, dan kami mendatangi sebuah sungai." Dan setahuku Samurah mengatakan; 'sungai merah seperti darah', "tak tahunya di sungai ada laki-laki yang berenang, sedang ditepi sungai ada orang 
yang mengumpulkan banyak bebatuan, apabila yang berenang tadi sampai ke tepian sungai, ke tempat orang yang mengumpulkan bebatuan, maka ia membuka mulutnya dan orang yang di tepi tadi memasukkan batu ke mulutnya, lantas ia berenang kemudian kembali lagi, setiap kali ia kembali ke tepi, mulutnya membuka dan orang yang di tepi menyuapinya dengan batu itu." Saya bertanya kepada dua orang yang membawaku; 'kenapa dua orang ini? ' keduanya menjawab; "adapun laki-laki yang berenang dalam sungai dan disuapi batu besar, mereka adalah pemakan riba." (HR. Bukhari no. 6525)

Orang-orang musyrik menyamakan riba dengan jual-beli, karena keduanya menghasilkan keuntungan; tambahan riba diambil ketika berakhirnya tempo hutang seperti halnya jual beli yang harganya diambil pada awal transaksi. Mereka tidak mengenal transaksi lain kecuali model seperti itu. Dan hal itu telah mendarah daging dalam jiwa mereka, sehingga menjadikannya dasar transaksi ekonomi.

Kemudian, Allah menjelaskan bahwa keduanya berbeda, dengan mengatakan "padahal Allah telah menghalalkan jual beli dan mengharamkan riba." Artinya bahwa jual beli terjadi karena adanya kebutuhan dan tidak ada unsur ketidakadilan di dalamnya, sedangkan riba semata-mata eksploitasi atau memanfaatkan kebutuhan orang yang terpaksa tanpa adanya imbalan yang seimbang. (Az-Zuhailî, 1998) Jual beli adalah transaksi yang menguntungkan kedua belah pihak, sedangkan riba merugikan salah satu pihak. Keuntungan pertama diperoleh melalui kerja manusia; sedang yang kedua, yang menghasilkan adalah uang bukan kerja manusia. (Shihab, 2000)

Rasulullah Saw. juga telah melarang mengambil riba, sebagaimana sabdanya:

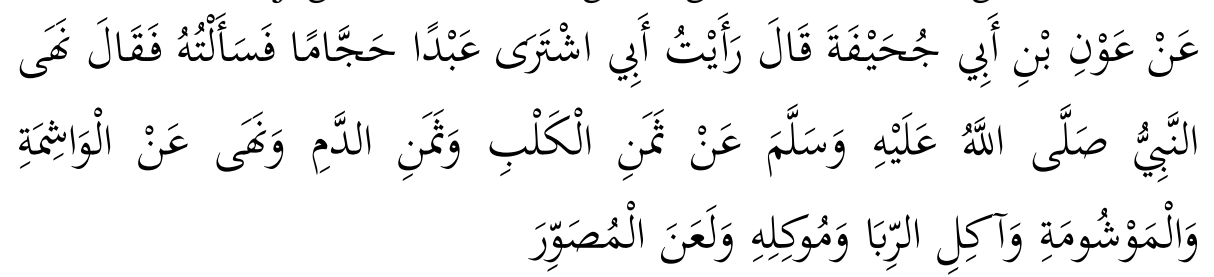

Dari 'Aun bin Abu Juhaifah berkata, aku melihat bapakku membeli seorang budak sebagai tukang bekam lalu aku tanyakan kepadanya maka dia berkata; "Nabi Saw. telah melarang harga (uang hasil jual beli) anjing, darah dan melarang orang yang membuat tato dan yang minta ditato dan pemakan riba' dan yang memberi riba serta melaknat pembuat patung". (HR. Bukhari no. 1944)

Kata ( وَحَرَّمَ الرِّبًَا ) dalam Qs. al-Baqarah: 275, maksudnya adalah Allah

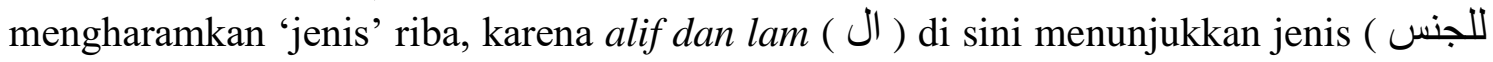
), bukan menunjukkan apa yang sudah dikenal pada masa lampau (للمعهود الذهني) yakni hanya riba jahiliyah atau riba nasî̀ah. Tetapi yang dimaksud oleh ayat tersebut adalah kemutlakannya, yaitu haramnya seluruh jenis riba. (Az-Zuhailî, 1998) Tidak ada beda antara riba dalam jumlah banyak ataupun sedikit. Sebagaimana sabda Rasulullah Saw:

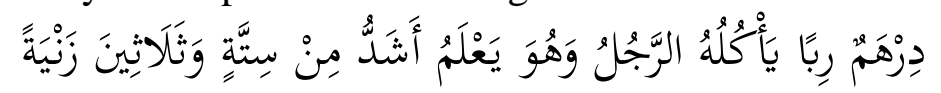

"Satu dirham uang riba yang dimakan oleh seseorang dalam keadaan ia tahu bahwa itu adalah uang riba dosanya lebih besar dari pada berzina sebanyak 36 kali." (HR. Ahmad dari Abdullah bin Hanzhalah dan dishahihkan oleh al-Albani dalam Shahih al-Jâmi', No. 3375) 
Dalam hadits di atas dengan tegas Rasulullah mengatakan bahwa uang riba haram meski sangat sedikit yang beliau ilustrasikan dengan satu dirham. Rasulullah Saw juga memasukkan riba dalam tujuh dosa besar yang membinasakan, sebagaimana sabdanya:

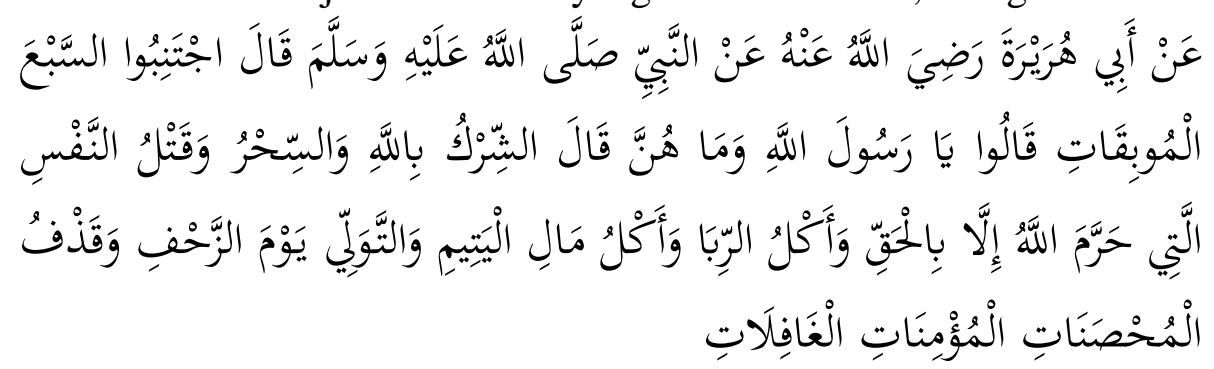

Dari Abu Hurairah r.a. dari Nabi Saw. bersabda: "Jauhilah tujuh perkara yang membinasakan". Para sahabat bertanya: "Wahai Rasulullah, apakah itu? Beliau bersabda: "Syirik kepada Allah, sihir, membunuh jiwa yang diharamkan oleh Allah kecuali dengan haq, memakan riba, makan harta anak yatim, kabur dari medan peperangan dan menuduh seorang wanita mu'min yang suci berbuat zina". (HR. Bukhari no. 2560)

Allah Swt juga memerintahkan untuk sabar menghadapi orang yang belum mampu membayar hutang. Lalu Allah menetapkan bahwa jika memang orang tersebut fakir, sedang mengalami kesulitan ekonomi dan belum mungkin membayar hutangnya pada waktu yang ditetapkan, maka hendaknya diberi tangguh dan tunggu hingga ia mampu. Sebagaimana Rasulullah Saw. bersabda:

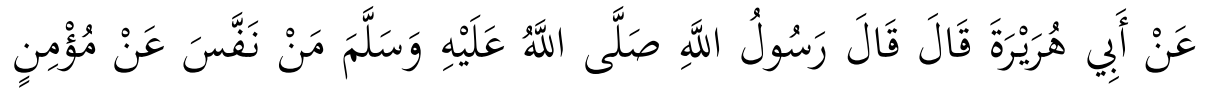

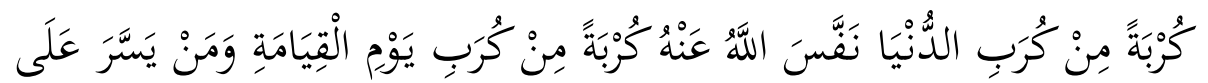

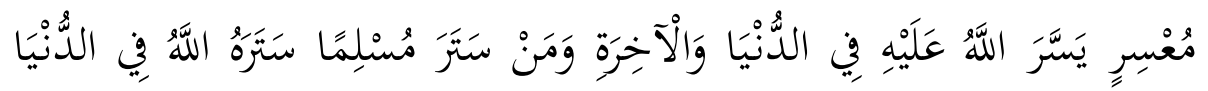

$$
\begin{aligned}
& \text { وَالْآخِرَة وَاللَّهُ فِي عَوْنِ الْعَبْدِ مَا كَانَ الْعَبْدُ فِي عَوْنِ أَخِيهِ }
\end{aligned}
$$

Dari Abu Hurairah dia berkata; Rasulullah Saw. bersabda: "Barang siapa membebaskan seorang mukmin dari suatu kesulitan dunia, maka Allah akan membebaskannya dari suatu kesulitan pada hari kiamat. Barang siapa memberi kemudahan kepada orang yang berada dalam kesulitan, maka Allah akan memberikan kemudahan di dunia dan akhirat. Barang siapa menutupi aib seorang muslim, maka Allah akan menutup aibnya di dunia dan akhirat. Allah akan selalu menolong hamba-Nya selama hamba tersebut menolong saudaranya sesama muslim." (HR. Muslim no. 4867)

Meskipun Allah memerintahkan untuk bersabar dan memberi tangguh kepada orang yang belum mampu membayar hutang, tetapi Allah juga menyebutkan bahwa memberinya sedekah dengan membebaskannya dari hutang itu lebih baik dari pada memberinya penambahan waktu pelunasan. Dan itu lebih banyak pahalanya di sisi Allah Swt. Rasulullah Saw. bersabda: 


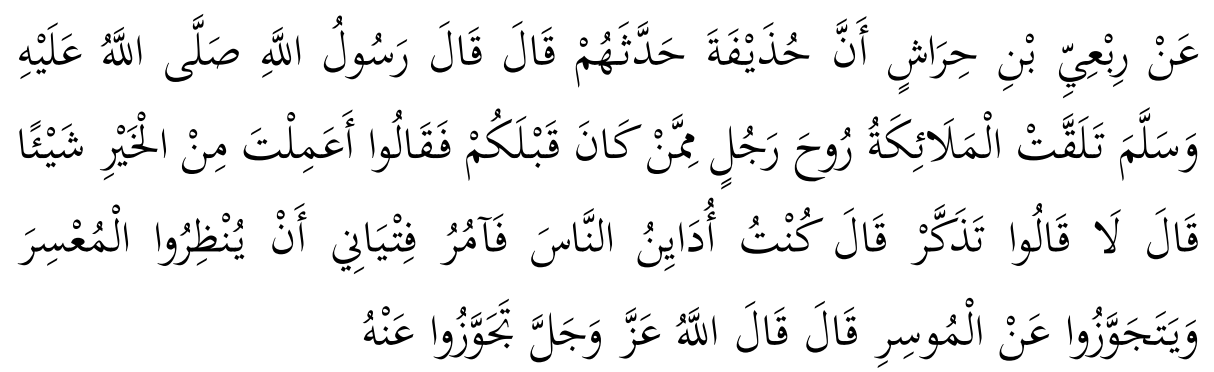

Dari Rab'i bin Hirasy bahwa Hudzaifah telah menceritakan kepada mereka, dia berkata: Rasulullah Saw. bersabda: "Beberapa Malaikat bertemu dengan ruh seseorang sebelum kalian, lalu mereka bertanya, 'Apakah kamu pernah berbuat baik?' Dia menjawab, 'Tidak.' Mereka berkata, 'Cobalah kamu ingat-ingat!' Dia menjawab, 'Memang dulunya saya pernah memberikan piutang kepada orang-orang, lantas saya perintahkan kepada pelayan-pelayanku agar memberikan tangguh kepada orang yang kesusahan, serta memberikan kelonggaran kepada berkecukupan'. Beliau melanjutkan: "Lantas Allah Azza wa jalla berfirman: 'Berilah kelapangan kepadanya'." (HR. Muslim no. 2917)

\section{KESIMPULAN}

Semua jenis riba diharamkan berdasarkan nash dari al-Qur'an maupun as-Sunnah. Al-Qur'an menyoroti praktek riba tidak hanya dalam konteks mikro, tetapi juga makro yang telah sistemik dan menimbulkan dampak yang luas serta membahayakan perekonomian secara umum. Karena itu, ayat-ayat yang berbicara tentang riba tidak turun secara sekaligus, tetapi secara bertahap melaui empat tahapan, seolah hal ini mengindikasikan bahwa untuk menghilangkan riba yang telah sistemik tidak bisa sekaligus, tetapi perlu tahapan-tahapan dan strategi yang terencana.

Diantara strategi yang Allah sebutkan langsung bergandengan dengan riba adalah zakat dan sedekah. Maka ini bisa dimaknai bahwa untuk menghadapi sistem ribawi yang telah menjadi instrumen ekonomi secara massif perlu digalakkan sedekah dan zakat. Karena riba dan zakat/sedekah memiliki sifat yang bertentangan. Dalam zakat/sedekah terkandung keikhlasan. Sementara riba terkandung pemerasan.

Namun, sebagaimana isyarat ayat tentang riba yang turun bertahap, maka strategi menggalakkan zakat dan sedekah pun harus bertahap, termasuk menjadikan zakat/sedekah sebagai bagian dari instrumen ekonomi.

\section{REFERENSI}

\section{Buku}

Antonio, Muhammad Syafi'i. 2005. Bank Syariah; Dari Teori ke Praktek, Cet-9, Jakarta: Gema Insani.

Al-Marâghî, Ahmad Mushthafâ. TT. Tafsîr al-Marâghî, Mesir: Syarikat al-Maktabah Al-Qurthubî, al-Jâmi' li Ahkâm al-Qur'an. 1964. Kairo: Dâr al-Kutub al-Mishriyyah, Ash-Shâbûnî, Muhammad 'Ali. 1999. Rawâ'i al-Bayân; Tafsîr Âyât al-Ahkâm min alQur'ân, Beirut: Dâr al-Kutub al-'Ilmiyyah

Az-Zuhailî, Wahbah. 1998. at-Tafsîr al-Munîr fi al-'Aqîdah wa asy-Syarî'ah wa alManhaj. Damaskus: Dâr al-Fikr 
Lajnah Pentashihan Mushaf al-Qur'an. 2009. Pembangunan Ekonomi Umat; Tafsir alQur'an Tematik, Jakarta: Lajnah Pentashihan Mushaf al-Qur'an

Shalâh ash-Shâwî dan Abdullah al-Mushlih. 2008. Fikih Ekonomi Keuangan Islam.Jakarta: Darul Haq,.

Shihab, M. Quraish. 2000. Tafsir al-Misbah. Jakarta: Lentera Hati

Zuhri, Muh. 1997. Riba dalam al-Qur'an dan Masalah Perbankan; Sebuah Tilikan Antisipatif. Jakarta: RajaGrafindo Persada

\section{Software al-Maktabat asy-Syâmilah v. 3.48.}

Al-Marghainânî, Syarh Bidayat al-Mubtadi， al-Maktabat al-Islâmiyyah, tt.

Al-Qurthubî, Ibn Abd al-Barr, al-Kâfî fî Fiqh Ahl al-Madînah al-Mâlikî, Beirut: Dâr alKutub al-'Ilmiyyah, tt.

Ash-Shaghîr, Asy-Syâfi'i, Nihâyat al-Muhtâj ilâ Syarh al-Minhâj, al-Maktabat alIslâmiyyah, tt.

Ath-Thabarî, Abu Ja'far, Jâmi' al-Bayân fî Ta wîl al-Qur'ân, Muassasat ar-Risâlah, 2000.

Ibn 'Abbâs, 'Abdullah, Tanwîr al-Miqbâs min Tafsîr Ibn 'Abbâs.

Ibn Mandzûr, Lisân al-Arab, Beirut: Dâr ash-Shâdir, tt.

Ibn Qudâmah, al-Mughnî, Riyadh: Maktabat Riyâdh Hadîtsah, 1981.

\section{Internet}

http://agustiantomingka.wordpress.com/2011/03/02/transaksi-derivatif-dalamperspektif-syariah-ii.

http://www.pesantrenvirtual.com/index.php?option=com_content\&view=article\&id=11 06\%3Ariba-dan-meta-ekonomi-islam\&catid=8\%3Akajian-ekonomi\&Itemid $=60$.

http://muslim.or.id/al-quran/riba-jahiliah.html 